\title{
Effects of Water Deficit Stress on Several Quantitative and Qualitative Characteristics of Canola (Brassica napus L.) Cultivars
}

\author{
Seyed Mohammad HOSSEINI*, Payman HASSIBI \\ Shabid Chamran University of Ahwaz, Department of Agronomy and Plant Breeding, \\ Iran; mohammadhoseini90@gmail.com ( ${ }^{*}$ corresponding author)
}

\begin{abstract}
Water deficit stress considered as one of the most important limiting factors for oil seed canola (Brassica napus L.) growth and productivity in Iran. To evaluate the effects of water deficit stress on some qualitative and quantitative characteristics of canola cultivars, this experiment in a greenhouse trial carried out as factorial based on completely randomized design with three replications in Shahid Chamran University of Ahwaz (Iran). Canola cultivars, including 'Hyola 308', 'Hyola 401' and 'RGS 003' as first factor, and the second one was three levels of water deficit stress, including stress at early stem elongation stage to early flowering $\left(\mathrm{D}_{1}\right)$, early flowering stage to early emergence of sacs $\left(D_{2}\right)$, beginning of stem elongation stage to early emergence of sacs $\left(D_{3}\right)$ and normal irrigation $(C$, as check). Results showed that the interaction between water deficit stress and cultivars affected biological yield, seed oil yields and harvest index $(p \leq 0.01)$, dry matter and economic yield $(p \leq 0.05)$. Water deficit stress reduced grain oil yields. 'Hyola 308' under stress at beginning stem elongation stage to early flowering had the lowest oil yields $\left(1.1 \mathrm{~g} \mathrm{plants}^{-1}\right)$ and 'Hyola 401' under non-stress conditions showed highest oil yields $\left(4.3 \mathrm{~g} \mathrm{plants}^{-1}\right)$. The decrease of oil yields at the flowering stage to stem elongation stage was more than the other stages. In addition, water deficit stress reduced harvest index in the three stress levels due to reduced economic yield and reduced biological yield. Stress susceptibility index for 'Hyola 401' at the beginning of stem elongation stage to early emergence of sacs was 0.914 and the 'Hyola 308 ' showed 1.12 at the beginning of stem elongation stage to early emergence of sacs respectively, which it can implies that 'Hyola 308' is more sensitive than 'Hyola 401' to water deficit stress.
\end{abstract}

Keywords: canola, economic and biological yield, oil yields, stress susceptibility index, water deficit stress

\section{Introduction}

Canola is one of the most important oil crops in the world (Bybordi, 2010). Oilseed canola plant (Brassica napus L.) is an important agricultural crop grown primarily for its edible oil and the meal that remains after oil extraction has value as a source of protein for the livestock feed industry (Jensen et al., 1996). Canola container valuable fatty acids and amino acid required by the human body, with 40-49 percent and 35-39 percent protein (after oil extraction) and oil respectively. Water deficit is one of the most significant stresses of agriculturally important crops, affecting growth, development and yield (Micheletto et al., 2007). Water deficit stress due to drought, salinity, or extremes in temperature is the main limiting factors for plant growth and productivity resulting in large economic losses in many regions of the world (Borsani et al., 2001). Water deficit stress has effect on vegetative and reproductive stages of canola. The effect of water deficit stress was more during reproductive growth than vegetative growth of rapeseed (Ghobadi et al., 2006). The effect of drought stress is a function of genotype, intensity and duration of stress, weather conditions, growth, and developmental stages of rapeseed (Robertson and Holland, 2004). Drought stress increased protein content. The occurrence time and intensity of drought differ annually in field. In the water deficit condition, tolerance genotypes having more ability for adapting that this is excellent factor for them. In contrast to the cultivated Brassica napus, the genetic diversity of its relatives may provide useful genes for improving this tolerance (Shaheed Siddiqui et al., 2008). Objective of this study was effects of Water Deficit Stress on Several Quantitative and Qualitative Characteristics of Canola (Brassica napus L.) Cultivars and effect of water deficit stress on reproductive and vegetative stages.

\section{Materials and methods}

This experiment in greenhouse of Shahid Chamran University of Ahwaz, Iran in 2008-2009 growing season carried out. The greenhouse was located in Ahwaz (Iran) at $31^{\circ} 20^{\prime} \mathrm{N}$ latitude, $40^{\circ} 48^{\prime} \mathrm{E}$ longitude, 18 meters above sea level. Sowing date was November 11, 2009. A factorial experiment based on completely randomized design conducted in three replications. Factors including different canola cultivars ('Hyola 308', 'Hyola 401' and 'RGS 003') and water deficit stress including stress at beginning stem elongation stage to early flowering stage (beginning of pollination) $\mathrm{D}_{1}$, at beginning flowering to early emergence of sacs $\left(D_{2}\right)$, from the beginning of stem elongation to early 
emergence of sacs $\left(\mathrm{D}_{3}\right)$ and normal irrigation $(\mathrm{C})$ as control. To supply of crop nutrients requirement fertilizers of urea, super phosphate and potassium nitrate with regard to each pot size used. The weight of pots in this experiment was $10 \mathrm{~kg}$. In each replication, 12 treatments and 4 pots per each treatment in total 144 pots in this experiment were available. Four seeds cultured in each pot. Before implementing of water deficit stress, when plants were in 36 day-old (the beginning of stem elongation stage); kept in optimum conditions of soil moisture. To applied water deficit stress weight method was used. Once every day all pots using a precision portable balance device with an accuracy of $\pm 5 \mathrm{~g}$ weighed, then moisture of pots based on the soil moisture curve were set. This method is easily adapted for potted plants. Irrigation based on 75 and 25 percent of AW (available water for plants) for non-stress and stress conditions respectively. AW calculated by the following formula:

AW=FC-PWP

Which FC is soil field capacity and PWP is soil permanent wilting point. Before implementing water deficit stress, plants kept under normal water condition for 36 days (to reach the beginning stem elongation stage). When the potential of soil moisture reached below of the soil field capacity and down to 75 percent of AW, irrigation was done to reach optimal moisture. However, at stem elongation and flowering stages, when all pots reached to $25 \%$ AW; stress was applied. Four seeds cultured per each pot after disinfection of pots. Provide nutrient value of $150 \mathrm{~kg}$ $\mathrm{ha}^{-1}$ super phosphate for phosphorus supply, required 150 $\mathrm{kg} \mathrm{ha}^{-1}$ of potassium nitrate to provide potassium and 300 $\mathrm{kg}$ of urea (100 kg per ha-1 at cultivation stage, $100 \mathrm{~kg} \mathrm{ha}^{-1}$ at stem elongation stage and $100 \mathrm{~kg} \mathrm{ha}^{-1}$ at flowering stage) for the supply of nitrogen applied. These values added to pots respect to the calculated weight of soil in each pot. At complete maturity stage, crop traits such as total dry matter, economic yield, biological yield, harvest index and oil yields measured and stress susceptibility index (SSI) was calculated (Fischer and Maurer, 1978). To measure of crop performance, four plants analyzed in each treatment.

Stress Susceptibility Index (SSI):

$\mathrm{SSI}=[1-\mathrm{Ys} / \mathrm{Yp}] / \mathrm{SI}$

$\mathrm{Si}=$ the stress in tensity and estimated as:

$\mathrm{Si}=\{1-(\mathrm{ys} / \mathrm{yp})\}$

ys $=$ Mean yield over of genotypes evaluated under stress conditions. $\mathrm{yp}=$ Mean yield over of genotypes evaluated under non stress conditions.

Ys $=$ Yield of each genotype in the stress condition.

$\mathrm{Yp}=$ Yield of each genotype in the non stress condition.

Statistical analysis of data and calculation of correlation coefficients between traits were perfumed using the SAS software.

\section{Results and discussion}

Based on variance analysis of shoot dry matter (Tab. 1) there were significant differences among cultivars and different levels of stress $(p \leq 0.01)$ and their interactions $(p \leq 0.05)$. The lowest amount of shoot dry matter (Fig. 1) was in 'Hyola 308' (23 g plants $^{-1}$ ) in water deficit stress at early stem elongation stage to rise early sacs and the highest amount of shoot dry matter was in 'Hyola 401' under normal conditions $\left(74 \mathrm{~g}^{\text {plants }}{ }^{-1}\right)$. Results showed that the flowering stage to stem elongation is the most sensitive to water deficit stress. In all cultivars, stress at the beginning of stem elongation reduced dry matter and lowest reduction of dry matter was in 'Hyola 401' in the stress condition. 'Hyola 401' can be more tolerant related to the other cultivars. Lawler and Comic (2002) expressed that in the water deficit stress conditions, reducing of shoot dry matter can be due to reduction of cell turgor pressure and chlorophylls. Sangtarash et al. (2009) reported that the

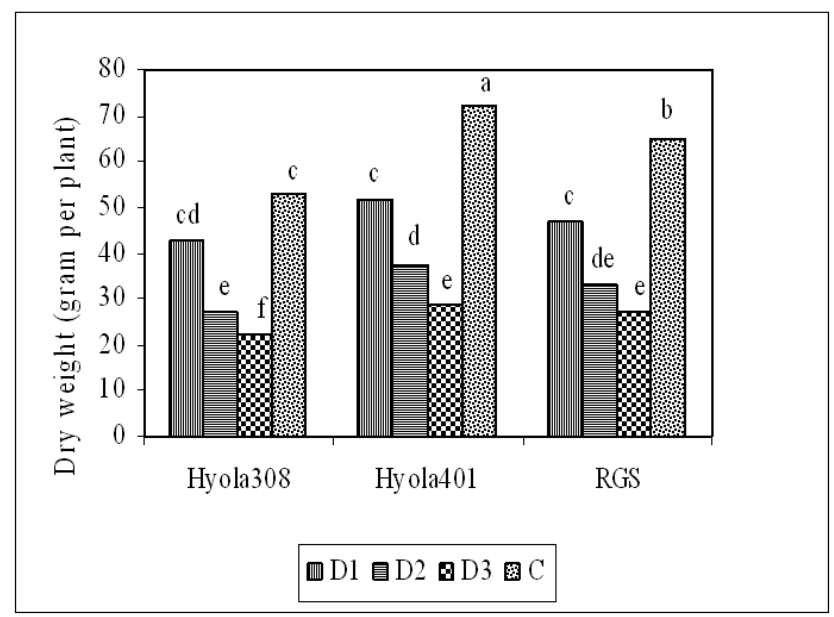

Fig. 1. Interaction of cultivars and water stress on shoot dry matter

Tab. 1. Analysis variance of dry matter, economic yield, biological yield, oil yields and harvest index

\begin{tabular}{ccccccc}
\hline S.O.V & df & Shoot dry matter & Economic yield & Biological yield & Oil yields & Harvest index \\
\hline Cultivars (C) & 2 & $62.25^{* *}$ & $6.63^{* *}$ & $599.11^{* *}$ & $2.92^{* *}$ & $25.53^{* *}$ \\
Stress (S) & 3 & $53.2^{* *}$ & $19.5^{* *}$ & $1109.96^{* *}$ & $6.90^{* *}$ & $13.07^{* *}$ \\
C $^{*}$ & 6 & $41.6^{*}$ & $4.15^{*}$ & $144.85^{* *}$ & $0.561^{* *}$ & $19.49^{* *}$ \\
Error & 24 & 18.72 & 1.27 & 14.30 & 0.28 & 0.50 \\
\%CV & & 3.8 & 14.04 & 10.71 & 7.56 & 3.78 \\
\hline
\end{tabular}

${ }^{* *}$ : Significant at $1 \%$ Probability level; ${ }^{*}$ : Significant at $5 \%$ Probability level 
122

water deficit stress condition decreased dry matter of individual plant and photosynthetic rate because biochemical restrictions in of water deficit condition, and reduced photosynthetic pigments, especially chlorophylls. Lowest rate of economic yield ( $4 \mathrm{~g}$ plants $\left.\mathrm{s}^{-1}\right)$ ) in stress conditions at the early stage of stem elongation to early emergence of sacs in 'RGS 003' and the highest in the normal condition of irrigation at 'Hyola 401' ( $9.1 \mathrm{~g} \mathrm{plants}^{-1}$ ) were obtained (Fig. 2). Therefore, in $D_{1}$, most economic yield of cultivars was in 'Hyola 308,' 'Hyola 401' and 'RGS 003'. In $\mathrm{D}_{2}$ most economic yield was in 'Hyola 401', 'RGS 003' and 'Hyola 308', in $\mathrm{D}_{3}$ was in 'Hyola 401', 'Hyola 308 ' and 'RGS 003 ' and in the control treatment most economic yield was observed in 'Hyola 401', 'RGS 003' and 'Hyola 308' respectively. Wright et al. (1995) compared compatibility of Brassica napus and Brassica juncea in water stress conditions. Results showed that both species decreased economic yield. Water stress reduced turgor pressure but it was higher in the Brassica napus species. The analysis of variance (Tab. 1) was determined that there were significant differences between biological yield of cultivars in different levels of water stress $(p \leq 0.01)$. Lowest rate of biological yield (14 g plants $\left.{ }^{-1}\right)$ in stress conditions in the early stage of stem elongation to early flowering $\left(D_{1}\right)$ of the 'RGS 003 ' cultivar and the highest amount in the normal conditions of 'Hyola 401' cultivar ( 59 g plants $^{-1}$ ) was observed (Fig. 3). In $\mathrm{D}_{1}$ most biological yield was in 'Hyola 401', 'RGS 003' and 'Hyola 308', and $\mathrm{D}_{2}$ in 'Hyola 401', 'Hyola 308' and 'RGS 003 ' cultivars respectively. In the third level of stress, highest biological yield in 'Hyola 401', 'Hyola 308' and 'RGS 003 ' respectively evaluated. In the control condition, highest biological yield was in 'Hyola 401', 'RGS 003' and 'Hyola 308', respectively. Gunasekara et al. (2006) observed 17.9 and $32.1 \%$ decrease the mean biological yield and 18.5 and $38.7 \%$ in moderate and high water stresses decrease the mean seed yield during reproductive growth compared to the control. Deepak and Watal (1995) have been observed a decrease in biological yield and sac dry matter in two canola cultivars, under water deficit conditions. Analysis of variance (Tab. 1 ) showed that there were significant differences of seed oil yields $(p \leq 0.01)$ between varieties and different levels of stress. In all tested cultivars, water stress reduced oil yields (Fig. 4). Highest oil yields rate in 'Hyola 401' (4.31 $\mathrm{g} \mathrm{plants}^{-1}$ ) of control condition and lowest rate of oil yields (1.3 $\mathrm{g}^{-1 a n t s^{-1}}$ ) in 'Hyola 308' variety in stress conditions of early flowering stage to early emergence of sacs was seen. Among different levels of stress condition, water deficit stress at the beginning of stem elongation to early flowering, showed the lowest impact in reducing the oil yields in three cultivars. In the control condition, most oil yields of seed obtained in 'Hyola 401', 'Hyola 308', and 'RGS 003' respectively. Among the tested cultivars in this experiment, 'Hyola 401' showed minimum reduction in the oil yields that can be cause of more tolerance of this cultivar to water stress. Sinaki et al. (2007) for determination of the effect of water deficit stress at dif- ferent growth stages of canola reported that at the time of occurrence of stress, oil concentration and the oil yields decreased. Also resulted that water stress in grain development stage was not effective on sink size but reduced the sources capacity and caused reduction of seed weight consequently. Ahmadi and Bahrani (2009) expressed that in

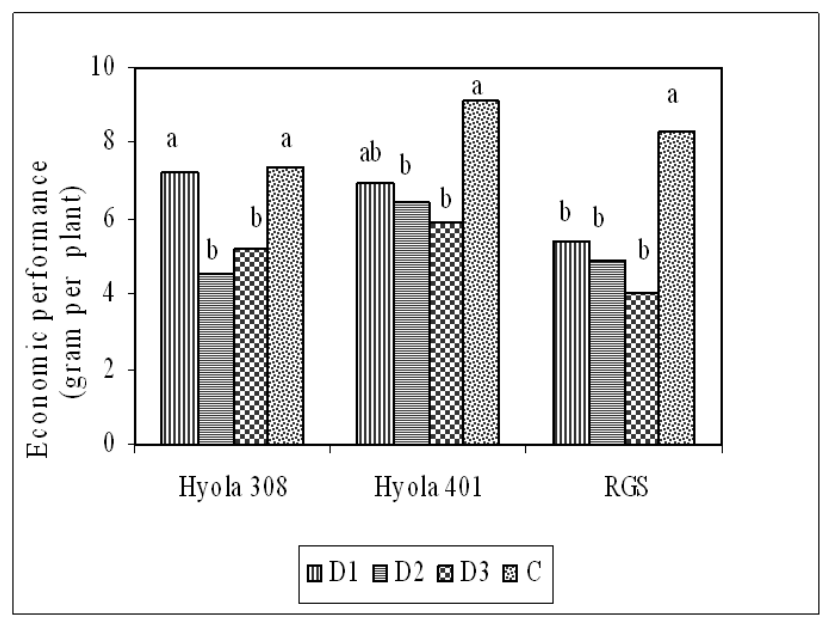

Fig. 2. Interaction of cultivars and water stress on economic yield

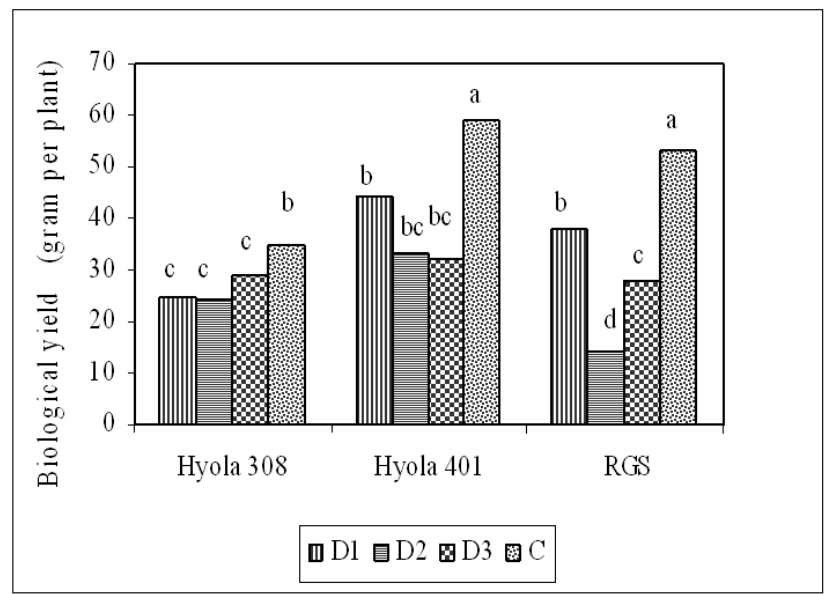

Fig. 3. Interaction of cultivars and water stress on biological yield

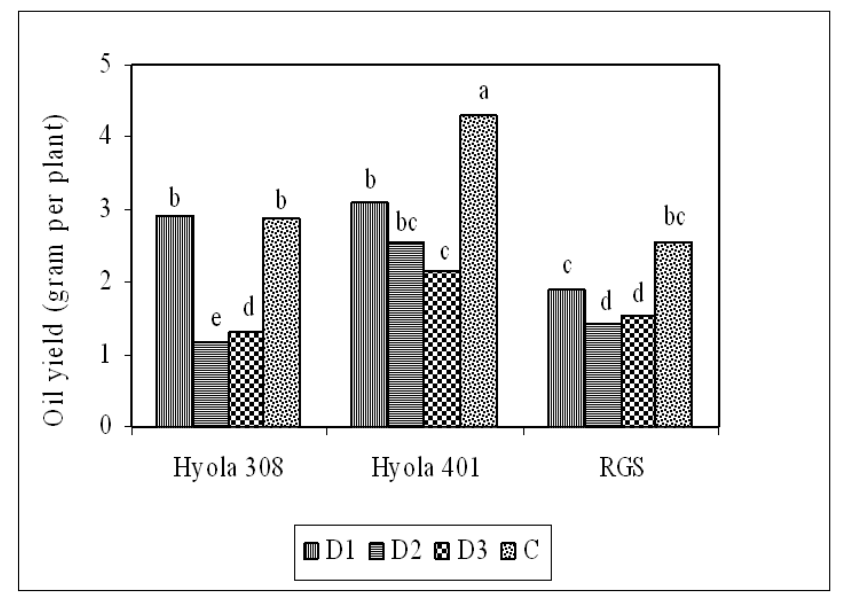

Fig. 4. Interaction of cultivars and water stress on oil yield 
Tab. 2. Stress susceptibility index in canola cultivars

\begin{tabular}{ccccc}
\hline & Levels of stress & Ys & Yp & SSI \\
\hline \multirow{3}{*}{ 'Hyola 308' } & $\mathrm{D}_{1}$ & 6.63 & 7.33 & 0.99 \\
\cline { 2 - 5 } & $\mathrm{D}_{2}$ & 5.26 & 7.33 & 1.05 \\
& $\mathrm{D}_{3}$ & 4.83 & 7.33 & 1.12 \\
\hline \multirow{3}{*}{ 'Hyola 401' } & $\mathrm{D}_{1}$ & 6.86 & 9.1 & 0.901 \\
& $\mathrm{D}_{2}$ & 6.36 & 9.1 & 0.906 \\
& $\mathrm{D}_{3}$ & 5.83 & 9.1 & 0.914 \\
\hline \multirow{3}{*}{ 'RGS 003' } & $\mathrm{D}_{1}$ & 5.4 & 8.3 & 0.925 \\
& $\mathrm{D}_{2}$ & 4.8 & 8.3 & 0.941 \\
& $\mathrm{D}_{3}$ & 4 & 8.3 & 0.941 \\
\hline
\end{tabular}

the water stress during reproductive stage of rapeseed (particularly flowering and sacs formation) was a critical period for seed and oil yields and caused reduction of sacs per plant. The results showed that there were significant differences among cultivars $(p \leq 0.01)$ different levels of stress and their interactions on harvest index (Fig. 5). This means that there was a significant difference between the different cultivars in terms of harvest index. Different levels of stress had also significant difference in harvest index of cultivars. The highest harvest index was in normal conditions (Fig. 5). Highest harvest index was in 'Hyola 308' and in the control condition (23\%) and the lowest in 'RGS 003 ' at stress conditions in beginning of stem elongation stage to early emergence of sacs $\left(\mathrm{D}_{3}\right)(16 \%)$ achieved, respectively. The effect of stress on harvest index at flowering stage was greater than stem elongation stage. The most harvest index was in 'Hyola 308', 'Hyola 401' and 'RGS 003 ' respectively, which indicates that 'Hyola 308' assigned more shares of, assimilates to the economic yield (seed) in stress condition. Tohidi-Moghadam et al. (2009) reported that water stress decreased total biomass, seed yield components, harvest index, and chlorophyll content. Soriano et al. (2002) showed that water deficits affected the harvest index of sunflower because the interactions between the timing and intensity of the stress. The obtained amount determined that 'Hyola 401' due to lower SSI (stress susceptibility index) than 'Hyola 308' and 'RGS 003 ' was less sensitive to water deficiency stress, and 'Hyola 308 ' had most susceptibility to water deficiency, The lowest SSI otained in the 'Hyola 401' and in $\mathrm{D}_{1}$, so this cultivar in the first level of water deficit stress was more tolerant to other cultivars. In addition, the higher SSI was

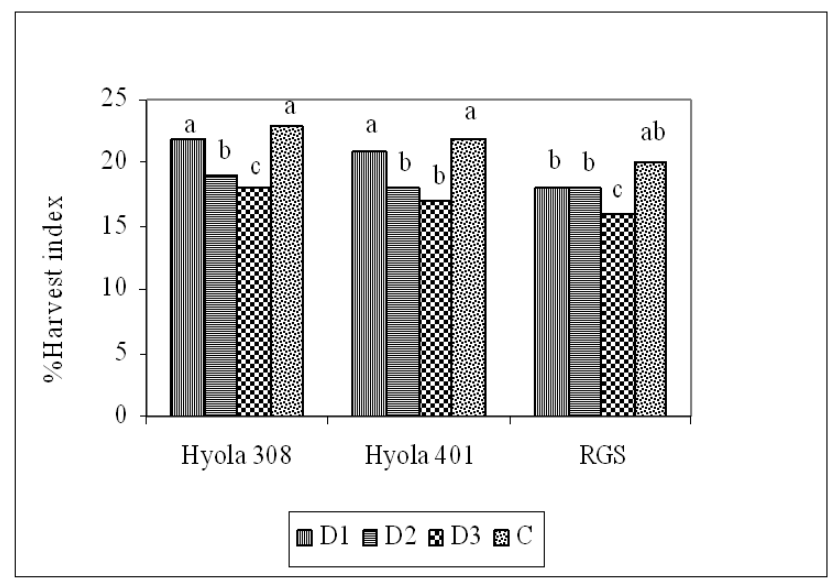

Fig. 5. Interaction of cultivars and water stress on harvest index; Similar letters in each column in terms of $5 \%$ statistical level are not significant; $\mathrm{D}_{1}=$ stress in the early stage of stem elongation to early flowering stage; $\mathrm{D}_{2}=$ stress in early flowering to early emergence of sac; $\mathrm{D}_{3}=$ stress in early stem elongation stage until early emergence of sacs; $\mathrm{C}=$ normal irrigation conditions (Control)

in the 'Hyola 308' in $\mathrm{D}_{3}$, therefore this cultivar in $\mathrm{D}_{2}$ was more susceptible to other cultivars (Tab. 2). Fischer and Maurer (1978) showed that less stress susceptibility index (SSI) shows a small variation in genotype yield and determined stability of genotype in stress condition. Clarke $e t$ al. (1992) used SSI for evaluation of drought tolerance in wheat genotypes and found the ssi is lower in the sensitive genotpes. In the first level of stress $\left(D_{1}\right)$, significant positive correlation between shoot dry matter and biological yield observed. Actually increasing dry matter raised biological yield (Tab. 3). Sanjari (1992) reported same results. In addition, a significant positive correlation between the oil yields and harvest index observed. With the increase in oil yields, harvest index also increased. Chaudhary et al. (1990) reported that grain yield has related to harvest index and caused increasing of dry matter and oil yields. There was a negative and significant correlation between stress susceptibility index and economic yield. The increase in SSI declined economic yield. Saulescu et al. (1998) showed that higher SSI under stress caused reduction of yield. In the second level of stress $\left(\mathrm{D}_{2}\right)$, significant positive correlation between dry matter with biological and economic yield with the oil yields observed. Increase of dry matter increased biological yield and increase of oil yields

Tab. 3. Correlation between dry matter, economic yield, biological yield, oil yields, harvest index and stress susceptibility index (SSI) characteristics in the first level of stress (stress in the beginning stage of stem elongation to early flowering, $\mathrm{D}_{1}$ )

\begin{tabular}{ccccccc}
\hline $\mathrm{D}_{1}$ & Shoot dry weight & Economic yield & Biological yield & Oil yield & Harvest index & SSI \\
\hline Shoot dry weight & 1 & & & & & \\
Economic yield & 0.421 & 1 & & & & \\
Biological yield & $0.698^{*}$ & 0.289 & 1 & 1 & & \\
Oil yield & 0.323 & 0.257 & 0.057 & $0.819^{* *}$ & $-0.609^{*}$ & 1 \\
Harvest index & 0.037 & 0.139 & 0.538 & -0.185 & & 1 \\
\hline SSI & -0.219 & $-0.702^{*}$ & -0.356 & & & \\
\hline
\end{tabular}


124

Tab. 4. Correlation between dry matter, economic yield and biological seed and oil, harvest index and stress susceptibility index (SSI) characteristics in the second level of stress (stress in early flowering stage to early emergence of sacs $\mathrm{D}_{2}$ )

\begin{tabular}{ccccccc}
\hline $\mathrm{D}_{2}$ & Shoot dry weight & Economic yield & Biological yield & Oil yields & Harvest index & SSI \\
\hline Shoot dry weight & 1 & & & & & \\
Economic yield & $0.617^{*}$ & 1 & & & & \\
Biological yield & $0.798^{* *}$ & 0.564 & 1 & 1 & & 1 \\
Oil yields & $0.638^{*}$ & 0.374 & 0.224 & 0.216 & -0.089 & 1 \\
Harvest index & 0.457 & 0.452 & 0.474 & -0.420 & $0.769^{*}$ & \\
\hline SSI & -0.435 & $-0.744^{*}$ & & & & \\
\hline
\end{tabular}

Tab. 5. Correlation between dry matter, economic performance, biological yield, oil yield, harvest index and stress susceptibility index (SSI) characteristics in the third level of stress (stress in the beginning stage of stem elongation to early emergence of sacs, $\left.\mathrm{D}_{3}\right)$

\begin{tabular}{|c|c|c|c|c|c|c|}
\hline $\mathrm{D}_{3}$ & Shoot dry weight & Economic performance & Biological yield & Oil yield & Harvest index & SSI \\
\hline Shoot dry weight & 1 & & & & & \\
\hline Economic yield & 0.199 & 1 & & & & \\
\hline Biological yield & $0.678^{*}$ & 0.129 & 1 & & & \\
\hline Oil yield & 0.253 & 0.257 & 0.097 & 1 & & \\
\hline Harvest index & 0.137 & 0.509 & 0.037 & $0.819^{* *}$ & 1 & \\
\hline SSI & -0.419 & $-0.754^{*}$ & -0.356 & $-0.665^{*}$ & -0.209 & 1 \\
\hline
\end{tabular}

Tab. 6. Correlation between dry matter, economic performance, biological yield, oil yield, harvest index and stress susceptibility index (SSI) characteristics in the control condition (normal condition, C)

\begin{tabular}{|c|c|c|c|c|c|c|}
\hline $\mathrm{C}$ & Shoot dry weight & Economic performance & Biological yield & Oil yield & Harvest index & SSI \\
\hline Shoot dry weight & 1 & & & & & \\
\hline Economic performance & 0.617 & 1 & & & & \\
\hline Biological yield & $0.798^{*}$ & 0.564 & 1 & & & \\
\hline Oil yield & 0.538 & $0.774^{*}$ & 0.224 & 1 & & \\
\hline Harvest index & 0.457 & $0.652^{*}$ & 0.474 & 0.216 & 1 & \\
\hline SSI & -0.435 & -0.44 & -0.420 & -0.69 & -0.089 & 1 \\
\hline
\end{tabular}

${ }^{* *}$ : Significant at $1 \%$ Probability level; ${ }^{*}$ : Significant at 5\% Probability level

increased economic yield (Tab. 4). Slafer and Andrade (1991) reported significant and positive correlation between grain yield and harvest index. Also at this level, a significant negative correlation between stress susceptibility index with economic yield and oil yields observed. With decreasing the economic yield and oil, yields increased SSI. In the third level of stress, $\left(D_{3}\right)$ significant positive correlation between dry matter with biological yield and oil yields with harvest index observed. With increasing dry matter, biological yield increased and with increased oil yields harvest index increased (Tab. 5). In addition, a negative correlation between economic yields with environmental sensitivity index observed that increasing economic yield, SSI declined. In the fourth level (Control condition or $\mathrm{D}_{4}$ ), significant positive correlation between economic yield with oil yields and harvest index, and a positive and significant correlation between economic yield with biological yield was observed (Tab. 6).

\section{Conclusions}

Results showed that water deficit stress decreased shoot dry matter and yields. Effect of water deficit stress depended to plant growth stages. The most susceptible stage to water deficit stress in the growth stage of canola was determined in the flowering stage, also the durable water deficit stress affected yields too. Cultivars were more susceptible in the beginning stage of stem elongation to early emergence of sacs because duration of stress. Water deficit stress in the beginning stage of stem elongation to early flowering showed lowest susceptibility to stress.

\section{References}

Ahmadi M, Bahrani MJ (2009). Yield and Yield Components of Rapeseed as Influenced by Water Stress at Different Growth Stages and Nitrogen Levels. American-Eurasian J Agric and Environ Sci 5(6):755-761.

Borsani O, Valpuesta V, Botella MA (2001). Evidence for a role of salicylic acid in the oxidative damage generate by $\mathrm{NaCl}$ and osmotic stress in Arabidopsis seedling. Plant Physiol 126:1024-1030.

Bybordi A (2010). Effects of salinity on yield and component characters in canola (Brassica napus L.) cultivars. Not Sci Biol 2:81-83. 
Chaudhary SK (1990). Path analysis for seed yield in safflower (Carthamus tinctorius L.) in acid soil under mid altitude conditions. International J Tropical Agric 8(2):129-132.

ClarkeJM,De Pauw RM, Townley-Smith TM(1992).Evaluation of methods for quantification of drought tolerance in wheat. Crop Sci 32:728-732.

Deepak M, Wattal PN (1995). Influence of water stress on seed yield of Canadian rape at flowering and role of metabolic factors. Plant Physiol Biochem 2:115-118.

Fischer RA, Maurer R (1978). Drought resistance in spring wheat cultivars. I. Grain yield response. Aust J Agric Res 29:897-912

Ghobadi M, Bakhshandeh M, Fathi G, Gharineh $\mathrm{MH}$, Alamisaeed K, Naderi A, Ghobadi V (2006). Short and long periods of water stress during different growth stages of canola (Brassica napus L.). Effect on yield, yield components, seed oil and protein contants. Agron J 5:336-341.

Gunasekara CP, Martin LD, French RJ, Siddique KHM, Walton V (2006). Genotype by environment interactions of Indian mustard (Brassica juncea L.) and canola (Brassica napus L.) in Mediterranean-type environments. Euro J Agron 25:1-12.

Jensen CR, Mogensen VO, Mortensen G, Andersen MN, Schjoerring JK, Thage JH, Koribidis J (1996). Leaf photosynthesis and drought adaptation in fieldgrown oilseed rape (Brassica napus L.). Aust J Plant Phys 23:631-644.

Lawler DW, Cornic G (2002). Photosynthetic carbon assimilation and associated metabolism in relation to water deficits in higher plants. Plant Cell and Environ 25:275294.

Micheletto S, Rodriguez-Uribe L, Hernandez R, Richins RD, Curry V, O'Connell MA (2007). Comparative transcript profiling in roots of Phaseolus acutifolius and $P$. vulgaris under water deficit stress. Plant Sci 173:510-520.

Robertson MJ, Holland JF (2004). Production risk of canola in the semi-arid subtropics of Australia. Aust J Agric Res 55:525-538.

Sanjari AGh (1992). Effect of yield component in grain yield in wheat. $1^{\text {th }}$ Iranian Agrobreed Congress Abstract Articles 2:6-9.
Sangtarash MH, Qaderi MM, Chinnappa CC, Reid DM (2009). Differential sensitivity of canola (Brassica napus) seedlings to ultraviolet-B radiation, water stress and abscisic acid. Environ Experim Botan 66:212-219.

Saulescu NN, Ittu Gh, Ittu M Mustatea P (1998). Breeding wheat for lodging resistance, earliness and tolerance to abiotic stresses, p.181-188. In: Braun HJ, Altay F, Kronstad WE, Beniwal SPS, McNab A (Eds.). Wheat: Prospects for Global Improvement (Eds) Kluwer Academic Publishers, Netherlands.

Shaheed Siddiqui Z, Ajmal Khan M, Kim BGi, Huang JS, Kwon T (2008). Physiological responses of Brassica napus genotypes to combined drought and salt Stress. Plant Stress 2:78-83.

Sinaki JM, Madjidi Heravan E, ShiraniRad AH, Noormohammadi GH, Zarei GH (2007). The effects of water deficit during growth stages of canola (Brassica napus L.). American-Eurasian J Agric Environ Sci 2(4):417-422.

Slafer GA, Andrade FH (1991). Changes in physiological attributes on the matter economy of bread wheat (Triticum aestivum) through genetic improvement of grain yield potential at different regions of the word. Euphytica 58:3749.

Soriano MA, Villalobos FJ, Fereres E (2002). Stress timing effects on sunflower harvest index, p.141-142. In: Villalobos FJ, Testi L (Eds.). VII Congress of the European Society for Agronomy.

Tohidi-Moghadam HR, Shirani-Rad AH, Nour-Mohammadi G, Habibi D, Modarres-Sanavy SAM, Mashhadi-AkbarBoojar M, Dolatabadian A (2009). Response of six oilseed rape genotypes to water stress and hydrogel application. Pesq Agropec Trop Goiânia 3:243-250.

Wright PR, Morgan JM, Jossep RS, Cass A (1995). Comparative adaptation of canola (Brassica napus L.) and indian mustard (Brassica juncea L.) to water deficit. Field Crop Res 42:1-13. 